\title{
Correlation between Reading Comprehension and Reading Strategy Used by English Students of FKIP UIR
}

\author{
Andi Idayani \\ Islamic University of Riau \\ E-mail: andiidayani@edu.uir.ac.id
}

\begin{abstract}
Reading strategies are skills under consideration which closely depend on specific reading contexts as well as reader awareness, control and intention. Strategies refer to mental actions deliberately employed to facilitate a reading process, to enhance reading comprehension and to overcome reading difficulties in order to achieve particular reading goal. The objective of this research is to find out the correlation between students' reading comprehension and reading strategy used by the third semester of English Students of FKIP UIR. The researcher used a quantitative method. This research was conducted on October 2018. The population of this research was the third semester of English students of FKIP UIR. The sample of this research was $3 d$ which consist of 37 students. The researcher used a questionnaire for reading strategy and reading test for reading comprehension. Based on the research findings, there was a medium correlation between students' reading strategy used and students' reading comprehension by the third semester of English students of FKIP UIR. The researcher found that in level significant $5 \% \mathrm{r}_{\mathrm{xy}}>\mathrm{r}_{\text {table }}=0.662>0.325$. Its means $\mathrm{H}_{\mathrm{a}}$ is accepted and $\mathrm{H}_{0}$ is rejected. In another words, there is significant relationship between students reading strategy used and students' reading comprehension.
\end{abstract}

Keywords: Reading Strategy, Reading Comprehension

ELT- Lectura: Jurnal Pendidikan, Vol 6, No1, February 2019 


\section{INTRODUCTION}

English as a foreign language for Indonesian students. Therefore, they need to have ability in reading because reading skill is one of crucial skill in English. It is also neccesary for them in second language learning situation for academic purpose. However, reading is useful activity because we can get knowledge, news, improve vocabulary, and develop a person's creativity. Reading in English is enhancing increasingly for the students. They need to be capable to acquire English texts. It is not only for study valuable or for entertain, but also for their careers in the future.

The process of building up and understanding the meaning from the text is called reading comprehension. It is neccesary for students to have strategy in which facilitate them easily in comprehending reading text. Therefore, Reading strategy helps students to know new information and how to make a good comprehension in reading with own knowledge.

Researcher found some of students' problem in the class, first, students feel difficult in reading comprehension because they still have lack of vocabularies. Second, they do not understand the differences between topic sentence and main idea. Third, the students cannot identify inferences. Inference means something that we can find out indirectly from what we already know or find out the conclusion of something.

The objective of the study is to identify the correlation between reading comprehension and reading strategy used by the third semester of English students of FKIP UIR.

\subsection{Concept of Reading Strategy}

According to Semry \& Mahendra (2015), reading strategy is one of crucial part in language learning strategies. Futhermore, reading strategy is intentional, aim directed attempt to manage and adapt the readers' effort to interpret text, understand words and compose meaning of text.

Reading strategies has been decided as plans and action for resolve the problems when readers' faced it in designing meaning (Janzen, 2003). He believes that topdown strategy is more comprehensive than bottom-up strategies. Such as, connecting what the readers have read with their background knowlegde is called top down strategies. On the other hand, bottom-up strategy is decided the informations which is presented in the data from text, for example comprehending the text by analyzing words and sentences in the text itself or by looking up an unfamiliar words in the dictionary.

From the explanation, we can conclude that reading strategy is a tool to comprehend the text. Reading strategy is a method; technique, procedure and an action for resolve the problem when the readers have difficulties in constructing meaning from the text.

\subsection{Components of Reading Strategy}

According Shoerey \& Mokhtari (2001), there are three categories of reading strategies in SORS (Survey of Reading Strategy): metacognitive strategies, cognitive strategies and support strategies.

Metacognitive reading strategies are defined as deliberate, carefully planned action employed by readers to monitor control their reading such as; setting the aims 
before reading, skimming or scanning the text to preview its length and structure. This definition is closely to what was O'Malley and Chamot (1990) previously stated, they explained that metacognitive strategies as managerial actions which consist of planning, monitoring or evaluating readers' learning process.

On the other hand, cognitive reading strategies are decided as the localized techniques used by readers while reading fastly with the text, especially when it becomes problem. Some examples are changing reading speed, inferring meaning from context, read several times for more comprehension and define the vocabulary. This definition is near similar to the teory of problem solving strategy suggested by Mokhtari and Reichard (2000). O’Malley and Chamot (1990) also dispute that cognitive strategies work directly on approching information, employing it in ways that reinforce learning process. Additionally, this strategy is dealing with the obstacles arising while reading process. It is said as typical characteristic of this group of strategies.

However, according to Mokhtari and Reichard (2000) in MARSI said that support strategies related with the use of core support mechanisms to aid comprehension. It is also appeared in the classification framework of Sheorey and Mokhtari (2001). Both studies conceptualized support strategies as implementing support mechanisms such as; take a note, use dictionaries, make summary, underline the key words, etc. to develop reading comprehension.

\subsection{Concept of Reading Comprehension}

Students have to develop their ability in acquiring the text and improve their skill in comprehending the text. It is caused that the reading comprehension has become crucial for them. The students' can success on reading depends on their ability to read. If they did not have good reading comprehension, it is possible for them get difficulty in reading and fail in learning process. Accroding to Presley (2000) mentions that the improvement of comprehension skill is a long-term process which depends on th experiences of students in reading and their language ability in building up the meaning of text.

Reading comprehension is the process of concurrently constructing meaning through interaction and connection with written language. (Snow, 2002). In this process, the reader, students, uses their background knowledge about the topic, language structure, and text structure to interpret the author's message. Then, the process of recognizing the message which is implicit or explicit in the text, the reader also needs to use several strategies like; predicting, clarifying, and confirming. Those are all strategies used by the reader for formulates the meaning after reading.

From the explanation stated, reading comprehension could be decided as the process of constructing the meaning from text, then correlate them with the reader prior knowledge in order to catch the cristal comprehending of message from author. 


\subsection{Component of Reading Comprehension}

According to King \& Stanley cited in Wahyu (2015) states that reading has five components formulated in reading text, they are:

\section{Finding Main Idea}

Main idea of paragraph tells the reader what the author's want the readers to know about the topic. Identifying the topic could commonly help the reader to comprehend the main ideas make particular statements or emphasizes a special aspect of the topic.

\section{Finding Factual Information}

Factual information requires students to find out the details information. It required to the reader to read specific details such a person, place, time, and events it is usually appear with $\mathrm{WH}$ question (where, why, what, when, how).

3. Finding the Meaning of Vocabulary

This component help the students to guess the meaning of the words by finding the synonym and antonym of words. If the word is not familiar with them, they could relate them with the context or topic of paragraph in every sentences that they read.

\section{Making Inference}

Inference in reading is the students' ability to comprehend the meaning of text without spelled out the all the information. So, from the context clues within a sentence, the writer gives information about plot, characters, setting, time period and other elements of story by the things he, she, it, they, our, etc. infers on the text.

\section{Identify Reference}

The writer always use various words to express the same purposes in order to use replicated words or phrases. It will help the reader/students to understand the reading passage as whole story.

\section{METHOD}

The design of this research is quantitative method. This research consist of two variables, namely students' reading strategy as the independent variable (symbolized by $\mathrm{X})$ and students reading comprehension as the dependent variable (symbolized by $\mathrm{Y}$ ). This research conducted at English language education of FKIP UIR. The population of this study was the third semester of English students of FKIP UIR. Because of the limited time and cost, purposive sampling was used in taking the sample. Purposive sampling means the process of choosing a sample in such a way that all individuals in the decided population had an equal and independent fortunate of being selected for the sample. In this research, the researcher chooses $3 \mathrm{~d}$ class as the sample of the research with the total students was 37 students.

\subsection{Instruments of the Research.}

The researcher need instrument to collect data. The researcher used two ways to collect data. 


\section{Questionnaire}

The researcher gives a reading strategy questionnaire to students. The questionnaire occupied in this research consists of 28 items, 25 of which were taken from Oxford et al (2004) and the other 3 were suggested by Sheorey and Mokhtari (2001). The scale of the questionnaire from 1-5 ( $1=$ Never, $2=$ Rarely, $3=$ Occasionally, 4=Frequently, 5=Always.). The 28 items were categorized into three groups: support strategies, cognitive strategies, and metacognitive strategies.

\section{Reading Test}

The researcher gives 25 questions about reading comprehension. The researcher uses an objective test with multiple choice type. This type could be scored easily, objectively and practically measure students' learning out come directly.

\subsection{Data Collection Technique}

In order to accomplishing the data, so we need to collect the data to suppose or determine the result finding of the research. In collecting data, the researcher gives questionnaire to students. Questionnaire uses to find out the data about the students' reading strategy as variable (X). Then, researcher gives a reading test to students. Test use to expose the data of students' reading comprehension as variable (Y).

\subsection{Data Analysis Technique}

The data was analyzed by using SPSS (Statistical Package for Social Science). A t-table was applied to answer the research question about the students' reading comprehension and their reading strategy used. Then, the data had been converted to coefficient of correlation.

According to Feblyza, A \& Afdal, Z (2015), coefficient of correlation is a number that is used as a base or instructions to find out how much the strength of the correlation between two or more variables.

In this study, Pearson Product Moment as formula used by reseacher to get the value of data. Product moment technique by Karl Pearson used to determine the correlation between two variables.

By using the formula, the researcher can get value of the correlation between reading comprehension and reading strategy. If the $-t_{\text {table }} \leq t_{\text {hitung }} \leq t_{\text {table }}$ it means that Ho is rejected. If $t_{\text {hitung }} \geq t_{\text {table, it }}$ means the Ha is accepted.

\section{FINDINGS AND DISCUSSION}

\subsection{Data Presentation}

After getting the data, the researcher presented them to be calculated based on formula in the previous chapter. Those data consist of two, they were questionnaire for reading strategy as variable $\mathrm{X}$ and reading test for reading comprehension as variable $\mathrm{Y}$. The researcher did the validation of reading test that consist of 29 students before doing the research. Then the researcher detects relationship between variable $\mathrm{X}$ and variable $\mathrm{Y}$ by analyzing the data using Pearson Product Moment formula.

\subsubsection{The Result of Reading Strategy}

One of the instruments of the research is questionnaire which was distributed to the students' in order to know the strategy used by students in reading. 
Table 1.

Reading Strategy Scores

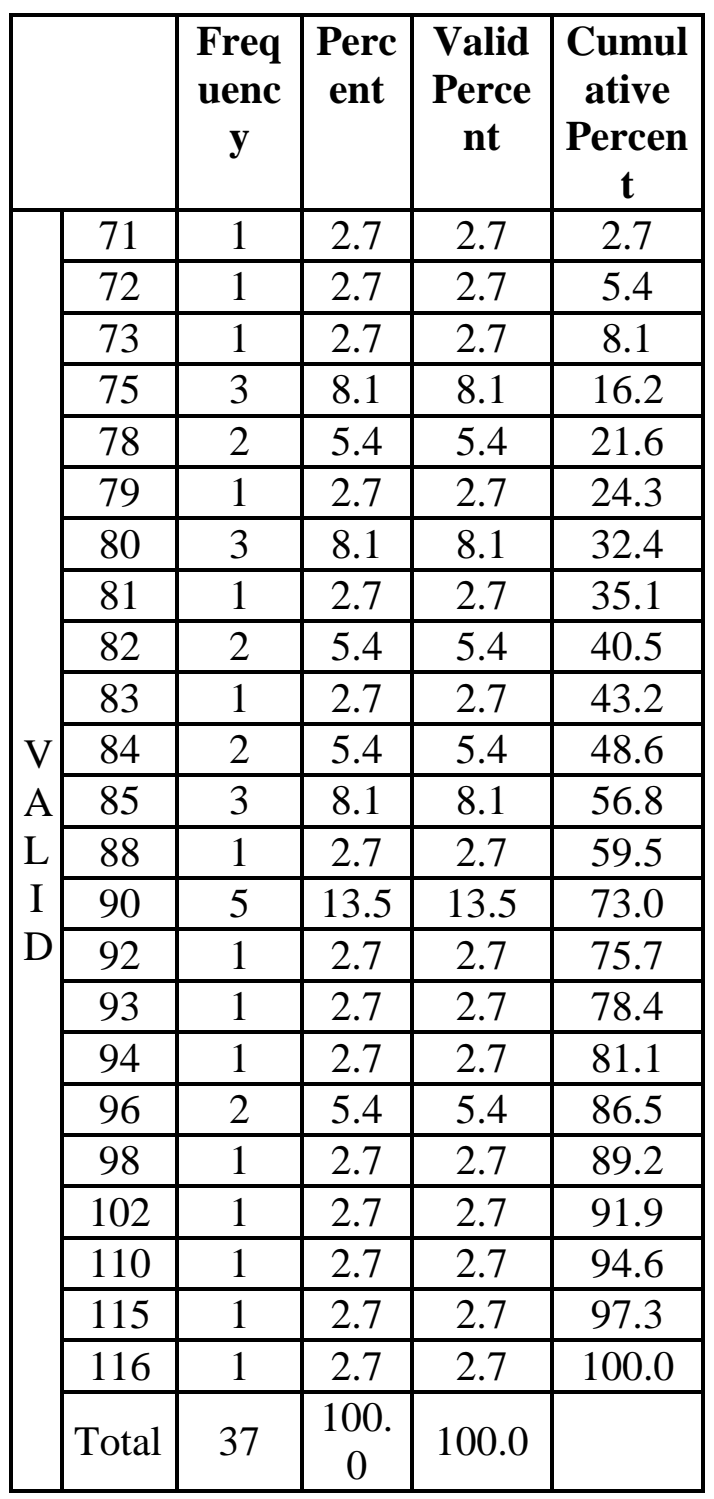

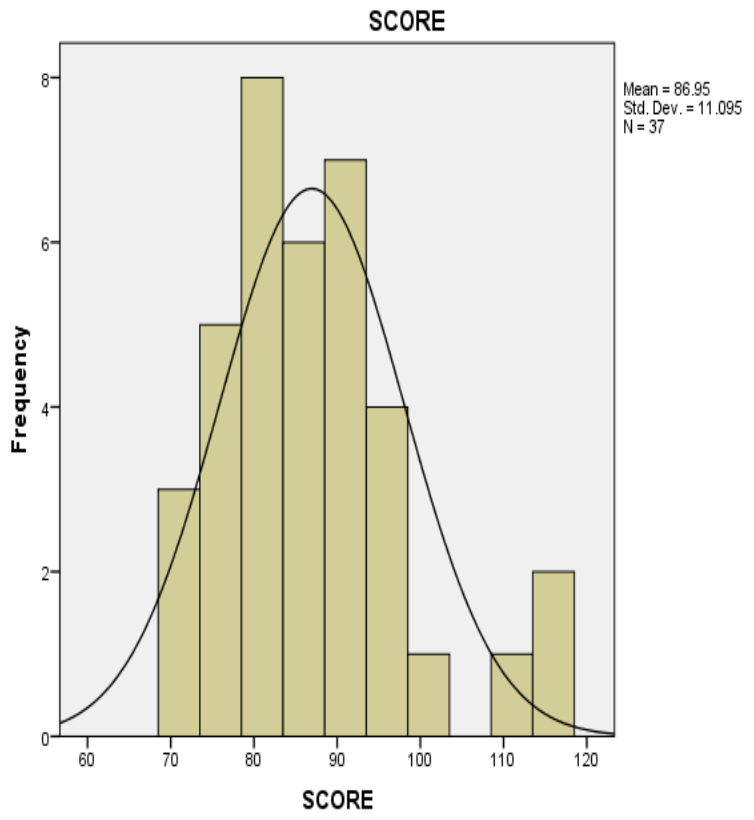

Figure 1. Histogram of Reading Strategy

Based on the histogram in figure 41 , it can be seen that the pattern of histogram was normal curve. Therefore, it can be concluded that the distribution of data was normal. The researcher also provided the students' mean scores were 86.95.

Table 2.

Students' level for each category of strategies

\begin{tabular}{|c|c|c|}
\hline & $\begin{array}{c}\text { Mean } \\
\text { Frequencies }\end{array}$ & $\begin{array}{c}\text { Level } \\
\text { of Use }\end{array}$ \\
\hline $\begin{array}{l}\text { Overall } \\
\text { reading } \\
\text { strategies }\end{array}$ & 3.15 & Medium \\
\hline $\begin{array}{c}\text { Metacognitive } \\
\text { reading } \\
\text { strategies }\end{array}$ & 3.24 & Medium \\
\hline $\begin{array}{l}\text { Cognitive } \\
\text { reading } \\
\text { strategies }\end{array}$ & 3.19 & Medium \\
\hline $\begin{array}{l}\text { Support } \\
\text { reading } \\
\text { strategies }\end{array}$ & 2.93 & Medium \\
\hline
\end{tabular}

By looking at the data on the table 1, we can concluded that the respondents' accumulative score in answering 28 questionnaire items were 3217 . The data were considered as data of reading strategy which in turn would be correlated to the data of reading comprehension. 
In this study, researcher used the level based on SILL's scale (Oxford, 1990), which classified a score of 1.0 - 2.4 as 'Low level', 2.5 3.4 as 'Medium level' and $3.5-5.0$ as 'High level'. Therefore, we can see that students' average frequency of overall strategy use was categorized at medium level $(\mathrm{M}=3.15)$, with the mean scores of individual strategies ranging from a high level of 3.84 to a low level of 2.00. There were 6 items of 28 strategies $(21.4 \%)$ falling into high use, 16 strategies (57.14\%) showing medium use, and 6 strategies (21.4\%) indicating low use.

Students' mean frequencies of using three categories of strategies were also rated at medium level. However, they showed metacognitive strategies are the most used $(M=3.24)$, then cognitive strategies $(M=3.19)$ and the last support strategies $(\mathrm{M}=2.93)$.

\subsubsection{The Result of Reading Comprehension}

Reading comprehension test was given after a questionnaire test. The researcher gets the score as the following:

Table 3.

Students Percentage of Reading Comprehension test

\begin{tabular}{ccc}
\hline Criteria & Students & Percentage \\
\hline $\begin{array}{c}\text { Excellent } \\
(90-100)\end{array}$ & 3 & $8.1 \%$ \\
\hline $\begin{array}{c}\text { Very Good } \\
(80-89)\end{array}$ & 16 & $43.2 \%$ \\
\hline $\begin{array}{c}\text { Good (70- } \\
79)\end{array}$ & 13 & $35.1 \%$ \\
\hline Average & 5 & $13.6 \%$ \\
\hline
\end{tabular}

$(60-69)$

Based on the result, the researcher could summarized that mean score of reading comprehension test was 78.5 which in good criteria. Three $(8.1 \%)$ students got Excellent in range 90-100, Sixteen (43.2\%) students got Very Good in range 8089, Thirteen $(35.1 \%)$ students got Good in range 70-79, and Five $(13.6 \%)$ students got Average in range 60-69.

\subsubsection{The Correlation of Reading Strategy and Reading Comprehension}

Based on the result of reading strategies and reading comprehension's scores, the research got the normality of them.

Table 4.

Normality Data of Variable $X$ and $\mathbf{Y}$

Tests of Normality

\begin{tabular}{|c|c|c|c|c|c|c|}
\hline & \multicolumn{3}{|c|}{$\begin{array}{c}\text { Kolmogorov- } \\
\text { Smirnov }^{\mathrm{a}}\end{array}$} & \multicolumn{3}{|c|}{ Shapiro-Wilk } \\
\hline & $\begin{array}{l}\text { Stat } \\
\text { istic }\end{array}$ & $\overline{\mathrm{df}}$ & Sig. & $\begin{array}{l}\text { Stat } \\
\text { istic }\end{array}$ & $\overline{d f}$ & Sig. \\
\hline $\begin{array}{l}\text { Reading } \\
\text { Strategy }\end{array}$ & .137 & 37 & .076 & .922 & 37 & .013 \\
\hline $\begin{array}{l}\text { Reading } \\
\text { Compre } \\
\text { hension }\end{array}$ & .137 & 37 & .075 & .953 & 37 & .121 \\
\hline
\end{tabular}

a. Lilliefors Significance Correction

From the result, it shows that both variables data are categorized as normal distributed because the value of significant are higher 0.05 .

The significant value of reading strategy is 0.013 , it means that $0.013>0.05$ and the significant value of reading comprehension is 0.121 , it means that $0.0121>0.05$. 
Table 5.

\section{The Result of Correlation Calculation}

\begin{tabular}{clcr}
\hline & & $\begin{array}{c}\text { Reading } \\
\text { Strategy }\end{array}$ & \multicolumn{1}{c}{$\begin{array}{c}\text { Reading } \\
\text { Comprehe } \\
\text { nsion }\end{array}$} \\
\hline \multirow{2}{*}{$\begin{array}{l}\text { Reading } \\
\text { Strategy }\end{array}$} & $\begin{array}{l}\text { Pearson } \\
\text { Correlatio }\end{array}$ & 1 & $.662^{* *}$ \\
\cline { 2 - 4 } & $\begin{array}{l}\text { Sig. (2- } \\
\text { tailed) }\end{array}$ & & .000 \\
\cline { 2 - 4 } & $\mathrm{N}$ & 37 & 37 \\
\hline \multirow{2}{*}{$\begin{array}{l}\text { Reading } \\
\text { Compre } \\
\text { hension }\end{array}$} & $\begin{array}{l}\text { Pearson } \\
\text { Correlatio }\end{array}$ & $.662^{* *}$ & \\
\cline { 2 - 4 } & $\begin{array}{l}\text { Sig. (2- } \\
\text { tailed) }\end{array}$ & .000 & \\
\cline { 2 - 4 } & $\mathrm{N}$ & 37 & 37 \\
\hline
\end{tabular}

From the table, the researcher explains that $r$ coefficient is 0.662 and the sig, (2-tailed) is 0.000 .. From the table, $r_{\text {result }}$ is included in the third category $(0.40-0.70)$ that describes there is a medium correlation between two variable $\mathrm{X}$ and variable $\mathrm{Y}$. The result showed $r_{x y}>r_{\text {table }}=$ $0.662>0.325$. Based on $t_{\text {test }}$ result, with the significance value 0.05 , the researcher got $\mathrm{t}_{\text {result }}>\mathrm{t}_{\text {table }}=5.220>$ 2.030 and it show significance correlation. It means $\mathrm{H}_{\mathrm{a}}$ is accepted and $\mathrm{H}_{0}$ is rejected. It could be summarized that the students' reading strategy used has a significant correlation with students' reading comprehension.

\section{CONCLUSION AND SUGGESTION}

Based on the research findings, students' average frequency of overall strategy was 3.15 it means in medium level. The most strategy used by students' is metacognitive strategy which in mean 3.24. And in the last position is support strategy which in mean 2.93. And in students' reading comprehension test, the average of students is 78.5 it means good criteria. There are three students got excellent in range 90-100, and five students got average in range 6069.

Based on the research finding from questionnaire and reading comprehension test, the researcher can be summarized that there is correlation between them. There was a medium correlation between reading strategy of students' used and reading comprehension of students' by third semester students of English students of FKIP UIR.

Based on the previous conclusion, the students should be more attentive with their reading strategy used and should implement some strategies in reading as effective learning tools in reading comprehension. They also can improve their reading comprehension by formulate the goals of reading and basic aspect of reading.

\section{REFERENCES}

Febliza, Asyti \& Afdal, Zul. (2015). Statistika Dasar Penelitian Pendidikan. Pekanbaru. Adefa Grafika.

Mokhtari, K \& Reichard, C. (2000) Development of the Metacognitive-awarenessofreading- strategiesinventory (MARSI). [Unpublished manuscript]. Oklahoma State University, Stillwater, Oklahoma, USA.

Presley, M. (2000). What Should Comprehension Instruction be Instruction of? Lawrence Erlbaum Associates.

Semry, A \& Mahendra. (2015). Reading Strategies among 
ESL Malaysian Secondary School Students. International Journal of Evaluation and Research in Education. Vol.4, No.2, June 2015. ISSN: 22528822 .

Sheorey, R. \& Mokhtari, K. (2001) Differences in the Metacognitive Awareness of Reading Strategies among Native and Non-native Readers. System, 29, pp. 431 449.

Snow, Catherine. (2002). Reading for Understanding: Toward an $R \& D$ Program in Reading Comprehension. Los Angeles: RAND.

Wahyu, Destri (2015). The Implementation of Genre Based Approach in Teaching Reading: A Case Study at SMPN 17 Pekanbaru. National Journal English Language Teaching (ELT). Vol. 1, No. 1, Maret 2015. 